\title{
Molecular Cloning and Heterologous Expression of Human Interferon Alpha2b Gene
}

\author{
${ }^{1,2}$ I. Made Artika, ${ }^{1,3}$ Yemima Budirahardja and ${ }^{1,4}$ Anna Lucia Ekowati \\ ${ }^{1}$ Eijkman Institute for Molecular Biology, Jalan Diponegoro 69, Jakarta 10430, Indonesia \\ ${ }^{2}$ Department of Biochemistry, Faculty of Mathematics and Natural Sciences, \\ Bogor Agricultural University, Darmaga Campus, Bogor 16680, Indonesia \\ ${ }^{3}$ Mechanobiology Institute, National University of Singapore, 5A Engineering Drive 1, 117411, Singapore \\ ${ }^{4}$ School of Medicine, Atma Jaya Catholic University of Indonesia, Pluit Raya No. 2, Jakarta 14440, Indonesia
}

Received 2013-08-13; Revised 2013-10-03; Accepted 2013-10-20

\begin{abstract}
Human alpha Interferons (hIFN $\alpha$ ) have been shown to have antiviral, antiproliferative and immunomodulatory activities. The human interferon alpha2b (hIFN $\alpha 2 b$ ), is one of the human interferon alpha2 sub variants, naturally synthesized as a polypeptide of 188 amino acid residues, the first 23 residues of which represents a signal peptide. In the present study, the hIFNa2b gene was expressed after being fused with Glutathione S-Transferase (GST) gene. The hIFNa2b gene was amplified from human genomic DNA by using a pair of specific primers, cloned into an Escherichia coli expression vector and expressed in $E$. coli cells under the direction of the tac promoter. The expressed protein was purified using a one-step affinity chromatography column containing immobilized gluthatione-bound resin. The purified protein was shown to react specifically with anti-human-interferon-alpha antibody, confirming that the protein was the human interferon alpha molecule. This strategy has the potential to be used as an alternative mean for production of pure human interferon $\alpha$ proteins for therapeutic purposes and for further studies on their molecular characterization and mechanism of action.
\end{abstract}

Keywords: Recombinant Human Interferon Alpha2b, Escherichia coli, Protein Expression, Protein Purification

\section{INTRODUCTION}

The Interferons (IFNs) are glycoproteins involved in antiviral, antiproliferative and immunoregulatory process. The human interferons have been classified into three major types, alpha (leucocytes), beta (fibroblasts) and gamma (immune). To variety of different threats, the diversity of IFN provides different immune response (Tan et al., 2009).

IFNs, namely recombinant human IFNa2a and IFN $\alpha 2 b$, have been approved by the U.S Food and Drug Administration for treatment of malignant tumors and viral diseases. Interferon therapy is used (in combination with chemotherapy and radiation) as a treatment for many cancers, AIDS related Kaposi's sarcoma and chronic hepatitis B and C. More than half of hepatitis C patients treated with interferon respond with viral elimination (sustained virological response), better blood tests and better liver histology (Salunkhe et al., 2009).

Human alpha interferons belong to a family of homologous proteins coded by a multiple gene family. The human interferon $\alpha$ genes are located on the short arm of Homo sapiens chromosome 9. All these genes lack introns. Among 13 IFN $\alpha$ genes, a total of 28 different sequence variants have been described. These variants differ from each other in one to four amino acid positions, but share the same receptor system and exert similar biological activities (Gull et al., 2013).

Corresponding Author: I. Made Artika, Eijkman Institute for Molecular Biology, Jalan Diponegoro 69, Jakarta 10430, Indonesia Tel: +62-21-3148694, Fax: +62-21-3147982 
The molecular weight of individual interferon protein varies from 19 to $20 \mathrm{kDa}$. The newly synthesized polypeptide consists of 188 and 189 amino acids, the first 23 of which constitute the hydrophobic signal peptide. This polypeptide is split off yielding the active mature form of interferon $\alpha$ which consists of 165 or 166 amino acids (Gull et al., 2013; Ningrum et al., 2013).

The hIFN $\alpha 2 b$ is one of the most studied hIFN $\alpha$. It has been used to treat a number of malignancies, with the ability to induce antiproliferative, antiviral, antineoplastic and immunomodulating activities. Substantial amounts of hIFN $\alpha 2 b$ are required for the pharmaceutical industry as well as therapeutic use (Azaman et al., 2010).

Recombinant DNA technology has now made possible the large-scale production of interferon proteins for pharmaceutical applications. Genes encoding human alpha interferons have been cloned and expressed in recombinant strains of microorganisms and their products have been isolated in a very pure form. E. coli has been the most widely used host cells for production of recombinant interferons. Apart from synthesis of human interferon in the cytoplamic space, production of hIFN $\alpha 2 b$ in the periplasmic space of $E$. coli, in order to facilitate its downstream processing, has also been studied and optimized (Tan et al., 2009).

The aim of the present study was the isolation, molecular cloning and heterologous expression in E. coli cells of hIFN $\alpha 2 b$ genes in the form of Glutathione STransferase (GST)-IFN $\alpha 2 b$ fusion proteins. This study was also intended to initiate development of strategy for large-scale production of pure human interferon $\alpha$ proteins for therapeutic purposes in Indonesia.

\section{MATERIALS AND METHODS}

\subsection{Isolation of Human Genomic DNA}

Blood samples were obtained from a healthy donor. Genomic DNA was prepared from human white blood cells essentially according to the Puregene rapid DNA purification protocol for whole blood. As much as $5 \mathrm{~mL}$ blood was mixed with $15 \mathrm{~mL}$ red blood cell lysis buffer and incubated at room temperature for 10 min. The mixture was then centrifuged at $1500 \mathrm{rpm}$ until a clear supernantant was observed. After discharging the supernatant, $1250 \mu \mathrm{L}$ of white blood cell lysis buffer was added and the mixture was gently homogenized. Following the addition of $5 \mu \mathrm{L}$ of RNAse $\left(5 \mathrm{mg} \mathrm{mL}^{-1}\right)$, the mixture was homogenized and then incubated at $37^{\circ} \mathrm{C}$ for $15 \mathrm{~min}$. Protein was precipitated by adding $833 \mu \mathrm{L}$ of $5 \mathrm{M}$ ammonium acetate. Following centrifugation at $3000 \mathrm{rpm}, 4^{\circ} \mathrm{C}$, for $15 \mathrm{~min}$, the supernatant was collected and the DNA was then precipitated by adding $3850 \mu \mathrm{L}$ of isopropanol. DNA was pelleted by centrifugation at $3000 \mathrm{rpm}, 4^{\circ} \mathrm{C}$, for $5 \mathrm{~min}$. The pellet was washed with $4165 \mu \mathrm{L}$ of 70 percent ethanol, dried and dissolved in Tris EDTA buffer. The purity of DNA was measured by spectrophotometry by determining the ratio of its absorbances at 260 and $280 \mathrm{~nm}\left(\mathrm{~A}_{260} / \mathrm{A}_{280}\right)$.

\subsection{Isolation and Nucleotide Sequencing of hIFN $\alpha 2 b$ Gene}

The hIFN $\alpha 2 \mathrm{~b}$ gene was isolated by using the standard PCR amplification technique (Salunkhe et al., 2009) using the isolated human genomic DNA as a template. A pair of specific primers was employed. The nucleotide sequence of the forward primer was GGCTCACCCATTTCAACCAGTC and for the reverse primer it was GTCCTCTGTAAGGGACTAGTGC. The DNA fragment generated was purified using the QIA quick PCR purification kit, cloned into the pGEM-T vector and then sequenced using the ABI Prism 377 genetic analyzer. Nucleotide sequencing was carried out from forward and reverse directions, using $\mathrm{T} 7$ sequencing

TAATACGACTCACTATAGGGCGA and SP6 sequencing primer, ATTTAGGTGACACTATAGAATAC, respectively.

\subsection{Cloning of hIFN $\alpha 2 b$ Gene into $E$. coli Expression Vector}

The hIFN $\alpha 2 b$ gene was cloned into the pGEX-4T-2 E. coli expression vector using standard methods (Green and Sambrook, 2012). Two versions of hIFN $\alpha 2 b$ genes, one with and one without the signal peptide coding sequence, were cloned. In order to facilitate inframe insertion of each gene into the expression vector, a pair of gene specific primers having restriction sites for BamHI and EcoRI was used to introduce these two restriction sites in the respective gene by using oligonucle-otide-directed PCR mutagenesis technique. 
For introduction of BamHI and EcoRI sites into the hIFN $\alpha 2 b$ gene with signal peptide coding sequence, the nucleotide sequence of the forward primer was CAACATCTACAGGATCCATGGCCTTGAC and for the reverse primer was CTGGCATACGAATTCAATGAAAATC. The PCR amplified DNA fragment was digested with enzymes BamHI and EcoRI, fractionated by electrophoresis and the gel containing DNA fragment corresponded to the hIFN $\alpha 2 b$ gene plus signal peptide coding sequence was sliced out. The DNA fragment was then purified and ligated to pGEX-4T-2 previously digested with the same enzymes. Similarly, to introduce BamHI and EcoRI sites into the hIFN $\alpha 2 b$ gene without signal peptide coding sequence, the nucleotide sequences of the forward and reverse primers were GCTCTGTGGGATCCTGTGATCTG and CTGGCATACGAATTCAATGAAAATC,

respectively. The PCR amplified DNA fragment was cut with BamHI and EcoRI enzymes, fractionated by electrophoresis and the gel containing DNA fragment corresponded to the hIFN $\alpha 2 \mathrm{~b}$ gene without signal peptide coding sequence was sliced out. Following purification, the DNA fragment was ligated to pGEX4T-2 previously digested with the same enzymes. The correctness of each generated recombinant plasmid was analyzed by performing nucleotide sequencing of positive clones for each recombinant plasmid.

\subsection{Expression and Purification of Recombinant hIFN- $\alpha 2$ b Protein}

Following the introduction of recombinant plasmids into E. coli BL21 host cells, protein expression experiments were carried out. Transformed BL21 cells were grown in $20 \mathrm{~mL} 2 \times \mathrm{YTAG}$ medium containing $1 \%$ $\mathrm{w} / \mathrm{v}$ yeast extract, $1.6 \% \mathrm{w} / \mathrm{v}$ tryptone, $100 \mathrm{mg} \mathrm{mL}$ ampicillin, $2 \% \mathrm{w} / \mathrm{v}$ glucose and $0.5 \% \mathrm{w} / \mathrm{v}$ sodium chloride at $370 \mathrm{C}$ overnight. As much as $5 \mathrm{~mL}$ of this culture was used to inoculate $100 \mathrm{~mL}$ new 2xYTAG medium. The culture was incubated at $220 \mathrm{C}$ until it reached an Optical Density $\left(\mathrm{OD}_{600}\right)$ of $0.6-0.8$. The expression of the interferon genes was induced by the addition of IPTG to give a final concentration of $0.1 \mathrm{mM}$ followed by incubation at $22^{\circ} \mathrm{C}$ for 3 to $6 \mathrm{~h}$. Cells were harvested by centrifugation and dissolved in PBS buffer containing $0.1 \mathrm{mM}$ Phenylmethylsulfonyl Fluoride (PMSF). Suspension was sonicated for $1 \mathrm{~min}$. Following the addition of $1 \%$ Tri-ton-X-100, the suspension was incubated on ice for $20 \mathrm{~min}$ followed by centrifugation. The supernatant was collected and passed through an affinity chromatography column containing an immobilized Glutathione-Separose-4B matrix. The flow through fraction was collected. The column was then washed several times with PBS buffer. The GST taggedhIFN $\alpha 2 b$ proteins were eluted by using elution buffer containing $10 \mathrm{mM}$ reduced glutathione in $50 \mathrm{mM}$ Tris$\mathrm{HCl} \mathrm{pH} \mathrm{8.0.} \mathrm{The} \mathrm{flow} \mathrm{through} \mathrm{and} \mathrm{eluted} \mathrm{fractions} \mathrm{were}$ analyzed using SDS-PAGE (Gasmi et al., 2011).

\subsection{Western Blot Analysis}

The protein bands generated from SDS-PAGE analysis were translated onto Polyvinylidene Fluoride (PVDF) membrane. The membrane was blocked by incubation 3 times in blotto solution (PBS buffer containing 5\% skim milk) for $15 \mathrm{~min}$. The membrane was incubated overnight in blotto solution containing anti-human interferon alpha 2 monoclonal antibody as the primary antibody. Following removal of unbound primary antibody, the membrane was blocked as before. The membrane was then incubated in blotto solution containing secondary antibody rabbit-anti-mouse-IgG conjugated to horseradish peroxidase at room temperature for $1 \mathrm{~h}$. The membrane was then washed and resulting protein bands were developed.

\section{RESULTS}

\subsection{Human Genomic DNA and hIFN $\alpha 2 b$ Gene}

The isolated human genomic DNA was of good quality having a DNA concentration of $840 \mathrm{ng} \mu \mathrm{L}^{-1}$. Ratio of its absorbance's at 260 and $280 \mathrm{~nm}\left(\mathrm{~A}_{260} / \mathrm{A}_{280}\right)$ was 1.8 , indicating that the DNA was pure. The genomic DNA was used as a template for PCR amplification of the hIFN $22 \mathrm{~b}$ gene. As expected, the PCR process resulted in a DNA fragment of 797 bp (Fig. 1). This fragment encompassed the putative $45 \mathrm{bp}$ of upstream region of hIFN $\alpha 2 b$ gene, 567 bp of hIFN $\alpha 2 b$ coding sequence and $185 \mathrm{bp}$ of downstream region of hIFN $\alpha 2 b$ gene. Following its nucleotide sequence analysis, the generated sequence was aligned with nucleotide sequence of interferon genes in the GenBank using standard methods. Results showed that the PCRamplified-DNA fragment harbor the hIFN $\alpha 2 b$ gene (Table 1) marked by Guanine (G) at position 137 and $\begin{array}{lll}\text { Adenine } & \text { (A) at position } 170 .\end{array}$ 
I. Made Artika et al. / American Journal of Biochemistry and Biotechnology 9 (4): 423-429, 2013

Table 1. The nucleotide sequence of human interferon $\alpha 2 \mathrm{~b}$ gene and the sequence of predicted encoded amino acids*

\begin{tabular}{|c|c|c|c|c|c|c|c|c|c|c|c|c|c|c|c|c|c|c|c|c|}
\hline \multirow[t]{2}{*}{1} & atg & gcc & $\operatorname{ttg}$ & acc & $\mathrm{ttt}$ & gct & tta & ctg & gtg & gcc & ctc & ctg & gtg & ctc & agc & $\operatorname{tgc}$ & aag & tca & agc & $\operatorname{tgc}$ \\
\hline & M & A & L & $\mathrm{T}$ & $\mathrm{F}$ & A & L & $\mathrm{L}$ & V & A & L & $\mathrm{L}$ & V & $\mathrm{L}$ & $\mathrm{S}$ & $\mathrm{C}$ & K & $\mathrm{S}$ & $\mathrm{S}$ & $\mathrm{C}$ \\
\hline \multirow[t]{2}{*}{61} & tct & gtg & $\mathrm{ggc}$ & tgt & gat & ctg & cct & caa & acc & $\mathrm{cac}$ & agc & ctg & ggt & agc & agg & agg & $\mathrm{acc}$ & $\operatorname{ttg}$ & atg & ctc \\
\hline & $\mathrm{S}$ & V & G & $\mathrm{C}$ & D & $\mathrm{L}$ & $\mathrm{P}$ & Q & $\mathrm{T}$ & $\mathrm{H}$ & S & L & G & $\mathrm{S}$ & $\mathrm{R}$ & $\mathrm{R}$ & $\mathrm{T}$ & $\mathrm{L}$ & $\mathrm{M}$ & L \\
\hline \multirow[t]{2}{*}{121} & ctg & gca & cag & atg & agg & aga & atc & tct & $\mathrm{ctt}$ & $\mathrm{ttc}$ & tcc & $\operatorname{tgc}$ & $\operatorname{ttg}$ & aag & gac & aga & cat & gac & $\mathrm{ttt}$ & gga \\
\hline & $\mathrm{L}$ & A & Q & $\mathrm{M}$ & $\mathrm{R}$ & $\mathrm{R}$ & I & $\mathrm{S}$ & L & $\mathrm{F}$ & $\mathrm{S}$ & $\mathrm{C}$ & $\mathrm{L}$ & K & D & $\mathrm{R}$ & $\mathrm{H}$ & D & $\mathrm{F}$ & $\mathrm{G}$ \\
\hline \multirow[t]{2}{*}{181} & $\mathrm{ttt}$ & $\mathrm{ccc}$ & cag & gag & gag & $\mathrm{ttt}$ & $\operatorname{ggc}$ & aac & cag & $\mathrm{ttc}$ & caa & aag & gct & gaa & acc & atc & cct & gtc & ctc & cat \\
\hline & $\mathrm{F}$ & $\mathrm{P}$ & $\mathrm{Q}$ & $\mathrm{E}$ & $\mathrm{E}$ & $\mathrm{F}$ & $\mathrm{G}$ & $\mathrm{N}$ & Q & $\mathrm{F}$ & $\mathrm{Q}$ & K & A & $\mathrm{E}$ & $\mathrm{T}$ & I & $\mathrm{P}$ & $\mathrm{V}$ & $\mathrm{L}$ & $\mathrm{H}$ \\
\hline \multirow[t]{2}{*}{241} & gag & atg & atc & cag & cag & atc & ttc & aat & ctc & $\mathrm{ttc}$ & agc & aca & aag & gac & tca & tct & gct & get & $\operatorname{tgg}$ & gat \\
\hline & $\mathrm{E}$ & $\mathrm{M}$ & I & $\mathrm{Q}$ & Q & I & $\mathrm{F}$ & $\mathrm{N}$ & $\mathrm{L}$ & $\mathrm{F}$ & $\mathrm{S}$ & $\mathrm{T}$ & $\mathrm{K}$ & $\mathrm{D}$ & $\mathrm{S}$ & $\mathrm{S}$ & A & A & W & D \\
\hline \multirow[t]{2}{*}{301} & gag & acc & ctc & cta & gac & aaa & ttc & tac & act & gaa & ctc & tac & cag & cag & ctg & aat & gac & ctg & gaa & gcc \\
\hline & $\mathrm{E}$ & $\mathrm{T}$ & $\mathrm{L}$ & $\mathrm{L}$ & $\mathrm{D}$ & $\mathrm{K}$ & $\mathrm{F}$ & Y & $\mathrm{T}$ & $\mathrm{E}$ & $\mathrm{L}$ & $\mathrm{Y}$ & Q & $\mathrm{Q}$ & $\mathrm{L}$ & $\mathrm{N}$ & $\mathrm{D}$ & $\mathrm{L}$ & $\mathrm{E}$ & A \\
\hline \multirow[t]{2}{*}{361} & $\operatorname{tgt}$ & gtg & ata & cag & ggg & gtg & ggg & gtg & aca & gag & act & $\mathrm{ccc}$ & $\operatorname{ctg}$ & atg & aag & gag & gac & tcc & att & $\mathrm{ctg}$ \\
\hline & $\mathrm{C}$ & V & I & $\mathrm{Q}$ & $\mathrm{G}$ & V & $\mathrm{G}$ & V & $\mathrm{T}$ & $\mathrm{E}$ & $\mathrm{T}$ & $\mathrm{P}$ & L & $\mathrm{M}$ & K & E & D & S & I & L \\
\hline \multirow[t]{2}{*}{421} & gct & gtg & agg & aаa & tac & $\mathrm{ttc}$ & caa & aga & atc & act & ctc & tat & $\operatorname{ctg}$ & aaa & gag & aag & aаa & tac & $\mathrm{agc}$ & cct \\
\hline & A & V & $\mathrm{R}$ & K & Y & $\mathrm{F}$ & Q & $\mathrm{R}$ & I & $\mathrm{T}$ & $\mathrm{L}$ & $\mathrm{Y}$ & $\mathrm{L}$ & $\mathrm{K}$ & $\mathrm{E}$ & K & K & $\mathrm{Y}$ & S & $\mathrm{P}$ \\
\hline \multirow[t]{2}{*}{481} & tgt & gec & $\operatorname{tgg}$ & gag & gtt & gtc & aga & gca & gaa & atc & atg & aga & tct & $\mathrm{ttt}$ & tct & $\operatorname{ttg}$ & tca & aca & aac & $\operatorname{ttg}$ \\
\hline & $\mathrm{C}$ & A & W & $\mathrm{E}$ & V & V & $\mathrm{R}$ & A & $\mathrm{E}$ & I & $\mathrm{M}$ & $\mathrm{R}$ & $\mathrm{S}$ & $\mathrm{F}$ & $\mathrm{S}$ & $\mathrm{L}$ & $\mathrm{S}$ & $\mathrm{T}$ & $\mathrm{N}$ & $\mathrm{L}$ \\
\hline \multirow[t]{2}{*}{541} & caa & gaa & agt & $\mathrm{tta}$ & aga & agt & aag & gaa & tga & & & & & & & & & & & \\
\hline & $\mathrm{Q}$ & E & S & L & $\mathrm{R}$ & S & K & E & $*$ & & & & & & & & & & & \\
\hline
\end{tabular}

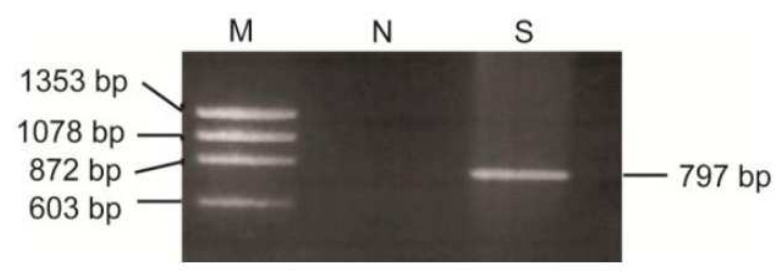

Fig. 1. PCR amplification of hIFN $\alpha 2 b$ gene. PCR was carried out using a pair of specific primers for human interferon $\alpha 2$. M, DNA marker; $\mathrm{N}$, negative control; S, sample

\subsection{Recombinant Plasmids pGEX-4T-2- hIFN $\alpha 2 b$ and pGEX-4T-2-hIFN $\alpha 2 b-w$}

Two versions of hIFN $\alpha 2 b$ genes, with and without the DNA segment encoding the signal peptide, were inserted into the E. coli expression vector pGEX-4T-2. PCR amplification using the primers to introduce BamHI and EcoRI sites into the hIFN $\alpha 2 b$ gene with signal pep-tide coding sequence, resulted in a DNA fragment of $630 \mathrm{bp}$. Following digestion with enzymes BamHI and EcoRI, a DNA fragment of 608 bp was generated. This fragment encompassed $567 \mathrm{bp}$ of hIFN $\alpha 2 \mathrm{~b}$ coding sequence and $41 \mathrm{bp}$ of its flanking sequences. The DNA fragment was then ligated to pGEX-4T-2 previously digested with the same enzymes (4960 bp) resulted in recombinant plasmid pGEX-4T-2hIFNa2b (5568 bp). Similarly, PCR amplification to introduce BamHI and EcoRI sites into the hIFNa2b gene without signal pep-tide coding sequence, resulted in a DNA fragment of $558 \mathrm{bp}$. Digestion of the fragment with BamHI and EcoRI enzymes resulted in a DNA fragment of $539 \mathrm{bp}$. This fragment encompassed $498 \mathrm{bp}$ of hIFN $2 \mathrm{2b}$ coding sequence and $41 \mathrm{bp}$ of its flanking sequences. Insertion of the fragment into pGEX-4T-2 previously digested with the same enzymes (4960 bp) resulted in recombinant plasmid pGEX-4T-2-hIFNa2b-w (5499 bp). The schematic diagram of the recombinant constructs is shown in Fig. 2. Nucleotide sequence analysis showed that the inserted hIFN $\alpha 2 b$ genes were in frame.

\subsection{Heterologously Expressed hIFN $\alpha 2 b$ Protein}

The two versions of hIFNa2b genes, with and without DNA segment encoding signal peptide, were heterologously expressed as fusion proteins with GST. As expected, protein bands of about $45 \mathrm{kDa}$ and $43 \mathrm{kDa}$ (Fig. 3) were generated following SDS-PAGE analysis. The protein bands of $45 \mathrm{kDa}$ and $43 \mathrm{kDa}$ corresponded to fusion proteins GST-hIFNa2b, with and without signal peptide, respectively. Western blot analysis of the 43 $\mathrm{kDa}$ protein (Fig. 4) showed that the protein reacted specifically to anti-human interferon alpha antibody confirming that the heterologously expressed protein was human interferon alpha. 

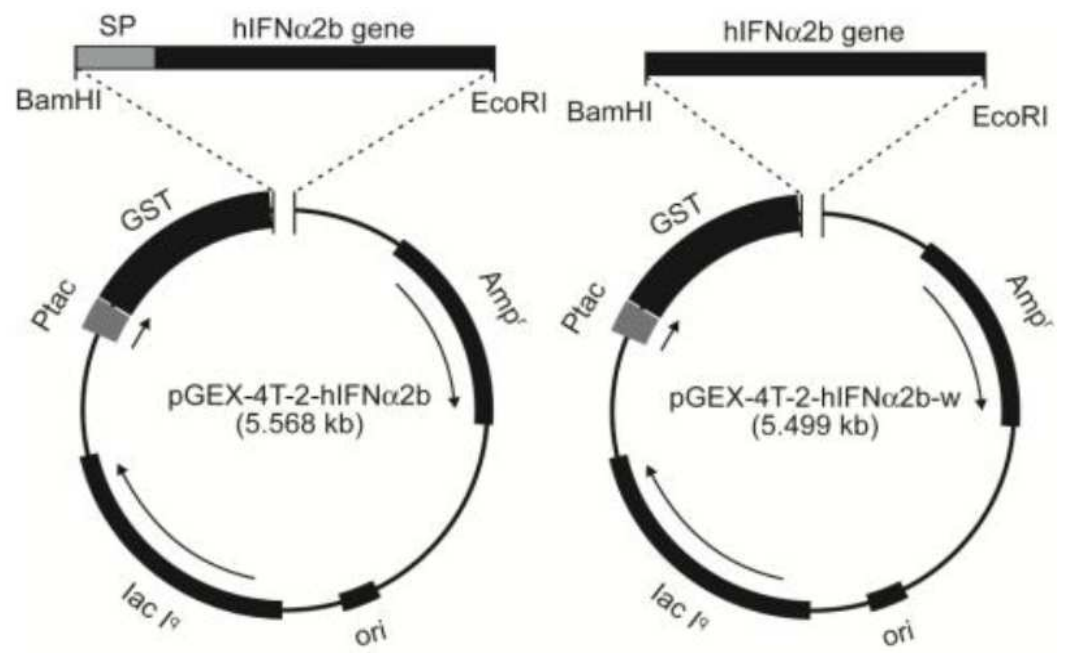

Fig. 2. Map for cloning of the human interferon $\alpha 2 b$ genes into the Eschericia coli expression vector. Schematic diagram of construction of recombinan plasmids pGEX-4T-2-hIFN $\alpha 2 \mathrm{~b}$ and pGEX-4T-2-hIFN $\alpha 2 \mathrm{~b}-\mathrm{w}$ is shown. The relevant restriction sites are indicated. $\mathrm{SP}=$ DNA segment encoding signal peptide, hIFN $\alpha 2 \mathrm{~b}$ gene $=$ the human interferon al-pha2b gene, GST $=$ Glutathione S-Transferase gene, $\mathrm{Amp}^{\mathrm{r}}=$ Ampicillin resistant gene, ori $=$ origin of replication, lac $\mathrm{I}^{\mathrm{q}}=$ lactose repressor gene, Ptac $=$ the $t a c$ promoter

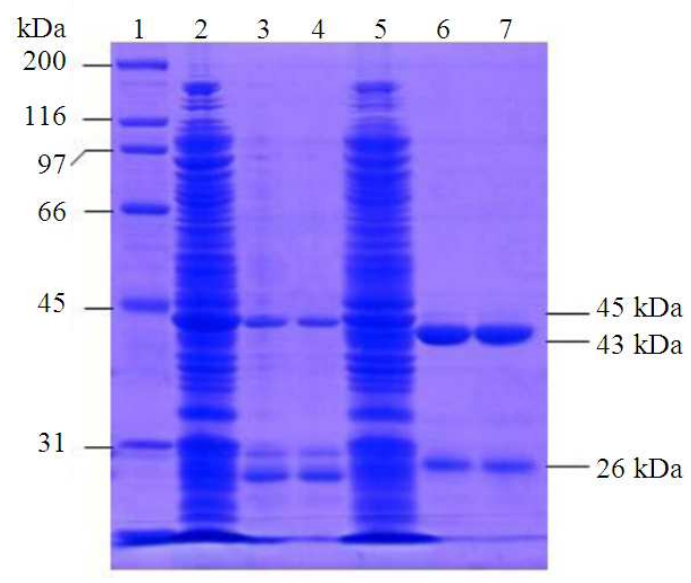

Fig. 3. SDS-PAGE analysis of GST-hIFN $\alpha 2 b$ protein expressed in Escherichia coli cells. The GST-hIFNa2b protein expression was carried out at $22^{\circ} \mathrm{C}$, induced by addition of IPTG for 3 to $6 \mathrm{~h}$. Cells were harvested and sonicated. The protein in the lysate was purified using affinity chromatog-raphy column containing immobilized Glutathione. The flowthrough and eluted fractions were analyzed. Lane $1=$ protein marker, lane 2 = flowtrough of GST-hIFN $\alpha 2 \mathrm{~b}$ with signal peptide, lane 3 and $4=$ eluted GST-hIFN $\alpha 2 \mathrm{~b}$ with signal peptide, lane $5=$ flowtrough of GST-hIFN $\alpha 2 b$ without signal peptide, lane 6 and $7=$ eluted GST-hIFN $\alpha 2 \mathrm{~b}$ without signal peptide

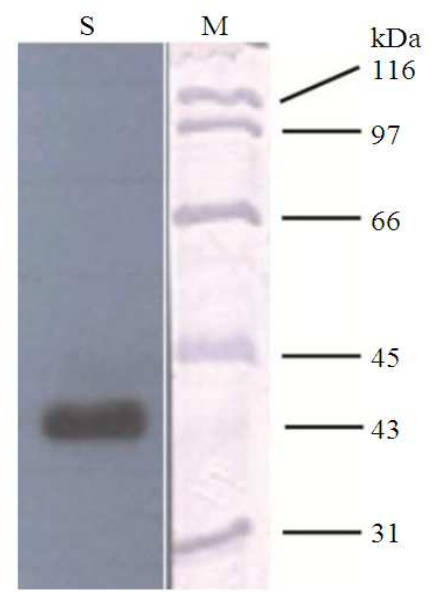

Fig. 4. Western blot analysis of GST-hIFNa2b protein. The protein bands generated from SDS-PAGE analysis were transblotted onto poliyvinylidene flouride (PVDF) membrane. The membrane was blocked and incubated overnight in solution containing antihuman interferon alpha2 monoclonal anti-body as primary antibody. Following removal of unbound primary antibody, membrane was blocked and incubated in solution containing secondary antibody rabbit anti-mouse-IgG conjugated to horseradish peroxidase at room temperature for $1 \mathrm{~h}$. Membrane was washed and protein bands were developed. $\mathrm{S}=$ sampel, $\mathrm{M}=$ protein marker 


\section{DISCUSSION}

In order to isolate the hIFN $\alpha 2 b$ gene from human genomic DNA to be cloned and heterologously expressed, the human genomic DNA was firstly isolated from human whole blood. Because the genomic DNA is only present in the nucleus of the white blood cells (lymphocytes), for genomic DNA isolation from whole blood, it is first necessary to remove erythrocytes using red-blood-cell lysis buffer. The genomic DNA was then released from white blood cells by using white-bloodcell lysis buffer. The white-blood-cell lysis buffer contained two major components, ethylene-DiamineTetraacetic Acid (EDTA) and Sodium-Dodecyl-Sulphate (SDS), which destroy membrane structure. EDTA removes magnesium ions that are important for maintaining the integrity of the cell membranes. It also inhibits the cellular enzymes which could degrade DNA. SDS aids the process of lysis by removing lipid molecules, thereby causing disruption of the cell membranes (Brown, 2010). The released genomic DNA was then purified by removing the two major contaminants, RNA and protein molecules. RNA was degraded using RNase and protein was removed by precipitation using ammonium acetate. Following precipitation using isopropanol, the genomic DNA was washed using $70 \% \mathrm{v} / \mathrm{v}$ ethanol to remove salt and small organic molecules. The resulting genomic DNA was then used as a template for PCR amplification of hIFN $\alpha 2 b$ gene. As the hIFN $\alpha 2 b$ gene contains no introns, the PCR-amplified hIFN $\alpha 2 b$ gene could directly be cloned into the pGEX-4T-2 expression vector following the introduction of flanking compatible restriction sites, BamHI and EcoRI sites. The hIFN $\alpha 2 b$ gene is marked by Guanine $(G)$ at position 137 and adenine (A) at position 170 .

For many purposes, it is important to produce interferon $\alpha 2 b$ in a highly purified form. In the present study, two versions of hIFNa2b genes, with and without the DNA segment encoding the signal peptide, were heterologously expressed in order to obtain $\mathrm{hIFN} \alpha 2 \mathrm{~b}$ molecules corresponding to both the newly synthsized and the mature forms. To facilitate their purification and detection, a strategy to express interferon $\alpha 2 b$ in the form of recombinant hybrid containing a polypeptide fusion partner termed a GST tag was developed. The main purpose of tagging the interferon proteins with GST is to facilitate their purification from whole cell extracts by affinity chromatography. Binding of proteins is based on the selective interaction between the GST tag and the immobilized glutathione of the affinity resin. The GST tag is a large affinity tag consisting of 220 amino acids $(26 \mathrm{kDa})$ forming dimer structures. Elution of the GSTtagged interferon protein was performed with free glutathione in the elution buffer. The affinity of GST for free glutathione is higher than the one for the immobilized glutathione bound to the agarose matrix. Therefore free glutathione replaces the immobilized glutathione which leads to release of the GST-hIFN $\alpha 2 b$ proteins from the matrix. The GST-tag can be detected using an enzyme assay or an immunoassay. Therefore, the GST-hIFN $\alpha 2 b$ proteins generated in the present study might be useful for preparation of pure hIFNa2b for therapeutic purposes. In addition, they may be of use for further molecular studies of hIFN $\alpha 2 b$ such as DNA-protein and protein-protein interactions to further elucidate their mechanism of action. When required, it is recommended to cleave the GST-tag from the fusion proteins by using a site-specific protease such as thrombin or factor Xa (Salunkhe et al., 2009).

The GST tagging was also intended to help in stabilizing the interferon protein and enhancing its solubility. The most challenging tasks in bacterial expression of foreign protein is the prevention of proteolytic degradation and accumulation of misfolded protein. Expression of proteolitically sensitive polypeptides by their fusion to other stable proteins has been shown to suppress degradation, although the mechanism responsible for the stabilization is not well understood (Salunkhe et al., 2009).

The insertion of the GST-hIFN $\alpha 2 b$ gene under the tac promoter was intended to yield high levels of transcription products which leads to high levels of synthesis of GST-hIFN $\alpha 2 \mathrm{~b}$ fusion protein. The tac promoter is a strong inducible promoter that gives very high rate of transcription initiation (Demain and Vaishnav, 2009). The tac promoter contains the lac operator sequence which is responsible for its transcription regulation. Synthesis of GST-hIFN $\alpha 2 b$ fusion protein was induced by addition of the lactose analog, IPTG, to the fermentation medium. The IPTG derepressed the binding of the lac repressor to the lac operator. IPTG is a convenient inducer for GST$\mathrm{hIFN} \alpha 2 \mathrm{~b}$ protein synthesis on the laboratory scale, but 
it may not be suitable for industrial fermentation as it is prohibitively expensive. Lactose can be used as an inexpensive inducer but it is somewhat weaker. Although the tac promoter is a "leaky promoter" because it always has a basal level of transcription, even in the absence of inducer, the $E$. coli BL21 host cells grew well under both noninducing and inducing conditions. This indicates that the GST-hIFN $\alpha 2 b$ protein may not be toxic to the BL21.

Production of interferons by recombinant techniques is favoured by the biotechnological industry because of its homogeneity and better productive yields. In the pre-sent study, E. coli BL21 was used as a host cell for expression of GST$\mathrm{hIFN} \alpha 2 \mathrm{~b}$ protein. The primary reasons were that it is easier to manipulate and grow than the cells of higher life forms. The BL21 is the most common bacterial host and this has proven to be outstanding in used in recombinant expression. In addition, it is deficient in omp T and lon, two proteases which may be harmful to the GST-hIFNa2b protein being expressed, hence these may interfere with the isolation of intact GSThIFN $\alpha 2 b$ protein. Although the optimal growth temperature for the E. coli $\mathrm{BL} 21$ cell is $37^{\circ} \mathrm{C}$, expression of the GST-hIFN $\alpha 2 \mathrm{~b}$ protein was carried out here at $23^{\circ} \mathrm{C}$. This lower temperature was employed so as to reduce proteolysis that may degrade the nascent GST-hIFN $\alpha 2$ b proteins and to avoid protein misfolding. Further studies are needed to test the activity of the expressed GST-hIFN $\alpha 2 \mathrm{~b}$ protein and to explore strategy to upscale its production in Indonesia.

\section{CONCLUSION}

The results presented show that a strategy has been develop to isolate, clone and heterologously express the human interferon $\alpha 2 b$ gene. The expressed proteins can be purified using a one-step affinity chromatography column. The strategy, therefore, has the potential to be used as a mean for production human interferon $\alpha 2 b$ proteins for various purposes.

\section{ACKNOWLEDGEMENT}

This study was supported by PT. Bio Farma, Bandung, Indonesia. We would like to thank Sangkot Marzuki and Herawati Sudoyo of Eijkman Institute for Molecular Biology, Jakarta, for guidance.

\section{REFERENCES}

Azaman, S.N.A., N.R. Ramakrishnan, J.S. Tan, R.A. Rahim and M.P. Abdullah et al., 2010. Optimization of an induction strategy for improving interferon- $\alpha 2 b$ production in the periplasm of Escherichia coli using response surface methodology. Biotechnol. Applied Biochem., 56: 141-150. DOI: 10.1042/BA20100104

Brown, T.A., 2010. Gene Cloning and DNA Analysis: An Introduction. 6th Edn., John Wiley and Sons, Hoboken, ISBN-10: 1444334077, pp: 336.

Demain, A.L. and P. Vaishnav, 2009. Production of recombinant proteins by microbes and higher organisms. Biotechnol. Adv., 27: 297-306. DOI: 10.1016/j.biotechadv.2009.01.008

Gasmi, N., A. Ayed, B.B.H. Ammar, R. Zrigui and J. Nicaud et al., 2011. Development of a cultivation process for the enhancement of human interferon alpha $2 \mathrm{~b}$ production in the oleaginous yeast, Yarrowia lipolytica. Microbial. Cell Factories, 10: 90-90. DOI: 10.1186/1475-2859-10-90

Green, M.R. and J. Sambrook, 2012. Molecular Cloning: A Laboratory Manual. 4th Edn., Cold Spring Harbor Laboratory Press, New York, ISBN-10: 1936113422, pp: 2000.

Gull, I., Samra, Z.Q., Aslam, M.S. and M.A. Athar. 2013. Heterologous expression, immunochemical and computational analysis of recombinant human interferon alpha 2b. SpringerPlus, 2: 264-264. DOI: 10.1186/2193-1801-2-264

Ningrum, R.A., A. Santoso and N. Herawati, 2013. Secretory expression of recombinant human interferon-alpha2b in methilotropic yeast Pichia pastoris. Int. J. Res. Pharm. Sci., 4: 207-210.

Salunkhe, S., B. Prasad, K. Sabnis-Prasad, A. ApteDeshpande and S. Padmanabhan, 2009. Expression and purification of SAK-fused human interferon alpha in Escherichia coli. J. Microbial. Biochem. Technol., 1: 5-10. DOI: 10.4172/19485948.1000002

Tan, J.S., R.N. Ramanan, S.N.A. Azaman, T.C. Ling and M. Shuhaimi, 2009. Enhanced interferon- $\alpha 2 b$ production in periplasmic space of Escherichia coli through medium optimization using response surface method. Open Biotech. J., 3: 117-124. 